The effect on the fossils which they contain is similar; these are sometimes enlarged into the most grotesque forms, and hence Agassiz was misled in distributing the fossil fish of the older rocks into eighty distinct species, a considerable number of which were of the same species but deformed in various ways so as to appear different.

Subsequently the members were present at the inauguration of a monument erected to the memory of Gosse, the founder of the Society. Much interest was attracted by the new geological map of the Republic exhibited in the hall. It has just been completed, and is the fruit of twenty-seven years of the labour of a number of geologists under the superintendence of $\mathrm{M}$. Alphonse Favre, who has now the satisfaction of seeing the end of this great task.

On the second day, in the Botanical Section, Prof. Müller, of Geneva, spoke of his systematic researches into the lichens of the Graphide group, of which he is about to make a general revision; Dr. Fischer, of Berne, described a new fungus (Hypocrea); Dr. Nuesch, of Schaffhausen, read a paper on the origin of Bacteria; and Prof. Schuetzler described a curious moss which grows at a depth of 200 feet in the sub-lacustrine moraine of Yvoire. It contains grains of chlorophyll perfectly formed, and is probably a variety of Thamnium alopecurum. Prof. Magnus, of Berlin, recounted his observations on the fecundation amongst aquatic plants, and more especially species of the Naias. M. Pittier spoke of the modifications being slowly made in the Vaudois flora, certain plants having disappeared wholly, while new ones have taken their places. M. Casimir de Canclolle described his investigations into the action' of low temperatures in germination.

In the Section of Zoology and Physiology Prof. Auguste Forel communicated a written memoir of the perception of violet by ants. He came to the conclusion that they perceived it with their eyes, and not through the skin. The so-called photodermatic sense does not appear to exist in ants, or at least is of small importance compared with ocular vision. M. Goll read a paper recording his observations on the fauna of Lower Egypt, especially of the fishes of Fayoum. There exists a well-marked distinction between the fauna of the desert and that of the Nile, particularly in colour. Dr. Zschokke gave some details on the development of the Scolex poly'morphus, a kind of parasitic worm which he studied at the Naples Zoological Station. He thinks that Wagener's classification of the Scolices is not a natural one. Prof. Blance, of Lausanne, continues his studies of the fauna of the Lake of Geneva, and presented a memoir on a new Protozoa which he discovered in a deep part of the lake, and which he names Gromia brunneri.

In the Geological Section Dr. Schmidt, of Freiburg in Brisgau, read a paper on the geological and mineralogical nature of the schists of the Grisons, which, it is now demonstrated, belong to the Jurassic. He spoke particularly of the mica which is one of their constituent elements. MM. de Fellenberg and Baltzer described the remains of great vegetable fossils found at Guttanen in the crystalline schists in the mass of Finsteraarhorn. M. Greppin exhibited a beautiful collection of fossils, not yet determined, of the oolite, found in the Jura in the neighbourhood of Basle. Prof. Renevier, of Lausanne, read a report on the excursions made by the Swiss Geological Society in the Vaudoise higher Alps during the five days preceding the meeting. M. Schardt described the geological structure of the Dent du Midi. M. Steinmann gave an account of a journey extending over two years in the Cordilleras of South America, between Bolivia and Patagonia. He sketched rapidly the characteristics of this great chain. The fossil fauna and flora are almost identical with those of European formations. The Upper Trias, Rhætian, Lias, Jurassic, and Cretaceous are all represented.

Of the pleasures as apart from the business of the meeting it is needless to speak. The Genevese authorities and people gave the members a hearty reception, and the whole town was en fête. Among the honorary members elected was Dr. J. H. Gladstone.

\section{THE BRITISH MEDICAL ASSOCIATION AT BRIGHTON}

THE annual meeting of the British Medical Association is anticipated not only as an occasion for the association and communion of medical men of all classes, but as an opportunity for, so to speak, taking stock of the progress of medical science and practice during the past year. From the choice of a locality near the metropolis, the meeting this year has been very successful, both as to the numbers attending it and the character of the papers read. From the tone of many of the addresses, indeed, it is easily perceived how intimately chemistry, physio$\log y$, biology, and even physics are becoming associated with medicine, and how, as a result of this, the special medical departments of pharmacology and therapeutics, pathology and hygiene, are being modified by scientific methods of investigation.

The subject chosen by the President, Dr. Withers Moore, for his address, viz. the higher education of women, was one which, though of interest to all classes of the community, did not lend much scope for the introduction of new matter. The chief argument on the medical aspect of the question brought forward by Dr. Moore was the statement that the extra tax on woman's intellectual faculties produced by this "higher education" lead's to bodily degeneration and to unfitness of the individual for a woman's peculiar social duties. This is admittedly so with those who are subjected to over-pressure; still, the questions as to how far these bad effects are general among the class of women who are subjected to severe intellectual training, and how far these bad effects may be counteracted by judicious hygienic surroundings, remain yet to be solved ; and the experiments in the higher education of women now being performed in America and Eng. land will no doubt yield results which will practically solve the question.

The address in Medicine, which was given this year by Dr. J. S. Billings, of the United States Army, dealt chiefly with medical politics in America, which, like our own country, needs reform in reference to medical edlication. It is interesting to note, from the remarks of one so well qualified to judge as Dr. Billings, the great progress made in America in the establishment of laboratories devoted to scientific medical investigation; and it may be confidently expected that by this means important contributions will be added to the stores of medical science.

It is in the departments of pathology and pharmacology that the influence of scientific thought and method is most evident. As Dr. Dreschfeld pointed out in his address before the Section of Pathology, there is in the modern study of pathology a great deal more than was comprised twenty or thirty years ago; for, besides the marvellous advances of morbid anatomy due to the improvement in histological methods and knowledge, the stimuJus of experimental physiology has initiated impor ant researches on various morbid processes. Indeed it is difficult to draw a hard-and-fast line between experimental physiology and patho$\operatorname{logy}$; for, in many instances, the investigation of physiological function proceeds pari passu with that of the loss or inhibition of that function. On the anatomical side pathology is seizing the facts discovered by purely scientific investigators, and applying them with good results. Thus, as Dr. Dreschfeld points out, the application of the researches of Flemming, Heuser, Rabl, anil others, on the composition of the nucleus, to the study of the cancer-cell, has shown that this is deficient in chromatin and embryonic in character. Again, the selective action of methyleneblue for certain nervous structures when injec ed into the living body, as described by Ehrlich, indicates a new method of pathological research by which the condition of these structures under the toxic action of substances may be investigated. If, moreover, as Ehrlich thinks, this selective action is due to the conditions of alkalinity and oxidation in the structure, some light may be thrown by future research on the still very obscure reactions of the nucleus and cell, and, more particularly in pathology, on the chemical changes occurring in the nerves in chronic peripheral paralysis due to poisons, such as alcohol and lead. Though a strong advocate of the study of experimental pathology, Dr. Dreschfeld insisted on the necessity of an investigator having a clear idea of the objeit and, as far' as possible, of the methods of the research which he is undertaking. This point, which is of course the basis of all useful experimentation, is very important in experimental pathology, owing to the peculiar conditions under which experiments on animals are performed in this country.

In pathology, which deals more closely with the facts of disease-disordered structure, disordered function-progress has been rapid, but not more so in its scientific aspect than pharmacology and therapeutics. A great deal of attention has of late years been devoted to this subject, as shown by the rapid accu. mulation of facts concerning old and new remedies. It is on such an occasion as the meeting of the Association that it is well to 
stand still for a moment and see the direction in which modern therapeutics is tending. Connected on the one hand with chemistry and physiology, and on the other with pathology and medicine, it is justifiable to expect that the recent advances in these departments of knowledge would have a stimulating effect on the progress of therapeutics.

Dr. Lauder Brunton, in his address (which we print in full) before the Section of Pharmacology, illustrated one aspect of this influence by discussing the connection between chemical constiturion and physiological action. It will readily be seen from a study of his remarks how important an effect the line of research which he indicated will have on the progress of rational therapeutics, which is based on a knowledge of the physiological action of a drug. Dr. Brunton's address shows a hopeful sign of advance in the treatment of disease by scientific methods and not by mere empiricism.

One of the most important communications made to the Association, and deserving of mention here, was that by Prof. O. Liebreich, of Berlin, on lanolin as a therapeutic agent. This substance, which is a cholesterin-fat from sheep's wool, is much more rapidly absorbed by the skin than glycerol-fats or vaselin, this property being probably connected with the fact that in nature it is closely associated with, if not formed by, keratin-containing cells, such as those of the skin, hair, feathers, \&c. Such a readily absorbable fat, which is unirritating, and will serve as a vehicle for medicaments, has long been a de sideratum, and it is probable that lanolin will be a most im portant agent in the treatment of skin diseases and of local disorders beneath the skin, as in the joints.

Space does not admit of a discussion of the numerous other interesting subjects, chiefly technical, introduced at the meeting of the Association. The interesting questions brought forward by Dr. Taafe in his address on public medicine included the spread of scarlatina by means of milk, a subject the investigation of which has been undertaken by the Local Government Board, and will no doubt yield important results to preventive medicine.

\section{O.V THE CONNECTION BETWEEN CHEMI- CAL CONSTITUTION AND PHYSIOLOGICAL $A C T I O N^{1}$}

THE meeting of the British Medical Association is not for mutual instruction only; it is also for recreation; and, probably, many members of this Association will utilise the opportunity which a meeting at the sea-side, like the present one at Brighton, affords them of indulging in that excellent occupation for an idle man-of watching the waves on the seashore and speculating how far each of them will come. If one have only half an hour to spare, it is difficult to say whether the tide is ebbing or flowing; it is only by watching for a longer time that one can be certain that the water is really moving in one direction or another. Probably a great part of the charm which this occupation possesses is due to the resemblance which one involuntarily traces between the e'bb and flow of waters and that of human affairs-individual, national, or racial. The life of a single man is very short in c mmparison with the history of race; and it is often very difficult to say whether mankind is advancing or retrograding, unless we compare his condition at epochs widely removed from one another.

On doing this, we find a general consensus of opinion, to the effect that civilisation has steadily advanced ; and this advancement is usually divided into four stages, characterised by the nature of the tools or weapons employed. In the first, or Palæolithic Age, man employed weapons or tools of flint roughly chipped into shape and unpolished. In the next, or Neolithic Age, the implements consisted of stone, but they were polished. The next age is characterised by the employment of bronze as a material, and the fourth and highest stage by the employment of iron. These stages are not all marked off from one another, for we find them together in the same country or in different countries. Thus, the age in which at present we live is recognised as the Iron Age, on account of the large employment of that metal but we find that in various countries stone, more or less rudely ashioned, is still used in the manufacture of weapons or tools.

I An Address delivered at the opening of the Section of Pharmacnlogy and Therapeutics, at the Annual Meeting of the British Medical Association held in Brighton, August r886. By Thomas Lauder Brunton, M.D., F.R.S. Lecturer on Materia Medica and Therapeutics at St. Bartholomew's Hospital; President of the Section.
For example, when I was in the Colonial Exhibition lately with Mr. Norman Lockyer, he pointed out a kind of threshing implement, such as is now used in Cyprus. It consists of a flat board, in the under side of which are embedded a number of stone celts exactly like those made by prehistoric man, and perhaps used by him for a similar purpose as well as for axes. In the same way that we recognise four stages in the development of the implements ueed by man in the arts or in warfare, we may, I think, recognise four stages in the development of the implements he has used in the treatment of disease. In the first stage crude drugs were employed, prepared in the roughest manner, such as powdered cinchona or metallic antimony. In the next stage these were converted into more active and more manageable forms, such as extracts or solutions, watery or alcoholic. In the third stage the pure active principles, separated from the crude drugs, were employed, e.g. morphine and quinine. In the fourth stage, instead of attempting to extract our medicines from the natural products in which they are contained, we seek to make for ourselves such substances as shall possess the particular action we desire. Now, just as we find stone and iron implements occasionally used together in the same country, so we find that drugs belonging to the different stages mentioned are used at the same time. For example, we may find crude powders, alco. holic extracts, and pure alkaloids all contained in the same pill. Nay more, we may sometimes give to the patient in addition to all these, a medicine made artificially. But, while this condition still $\epsilon$ xists, we notice that crude drugs are being less and less used, and their place is gradually being taken by pure active principles. We may say, then, that we are passing at present from the Stone Age into the Bronze Age of pharmacology ; and may indeed be said to be just entering on the Iron Age. This age may be said to have begun about twenty years ago, when the researches which my predecessor in this office, Dr. Fraser, made with Prof. Crum Brown upon the connection between physiological action and chemical constitution, inaugurated a new era in pharmacology. They found that, by modifying the chemical constitution of strychnine, they could also alter it physiological action, and convert it from a poison which would tetanise the spinal cord into one which would paralyse the motor nerves.

We might perhaps date the beginning of this age from Blake's attempts to show that a connection exists between the form in which various bodies crystallise, and the mode in which they act upon an animal body. Richardson, too, had observed that, amongst various compounds of carbon, certain differences existed in physiological action which might be supposed to correspond to differences in their chemical composition. And at the same time that Crum Brown and Fraser were making their experiments, Schroff in Vienna, and Jolyet and Cahours in France, had independently arrived at somewhat similar conclusions ; nevertheless, I think we may fairly say that it was the experiments of Crum Brown and Fraser which fairly started pharmacology in the new direction in which it has since been steadily advancing. It would be impossible for me to enter at all fully into the recent development of this branch of research, but I think it may be both interesting and useful to try to give you a short and popular account of the chief points already made out ; and, in doing so, I may perhaps be excused for using, almost to the extent of abusing, similes which are not precisely exact, but which may be useful in giving you a rough idea of a somewhat complicated subject.

We have all heard of the "flesh-pots of Egypt" ; but I find that everybody is not acquainted with the "flesh-pots of Shiloh," though "good little Samuel " has probably been frequently held up before us as an example to be followed, and possibly the naughty sons of Eli as an example to be avoided. When these sons of Eli were priests in Shiloh, their custom was, when any man offered a sacrifice, to send their servants with a "fleshhook" of three teeth, in his hand, which he struck into the pan, or kettle, or cauldron, or pot; and all that the flesh-hooks brought up the priest took for himself.

It is obvious that what the priest's man brought up would depend very greatly on two things, viz. the contents of the pot and the nature of the hook-whether it were large or small, sharp or pointed, single-pronged or many-pronged. It is obvious, too, that a very slight alteration of the points, by the judicious application of a file or whetstone, might considerably influence the savouriness of the priest's dinner. With the small pots that they were likely to have in Shiloh, it would not matter much what the nature of the handle was; but it would matter 